\title{
The Interrelationship of Autonomy, Motivation, and Academic Performance of Persian L2 Learners in Distance Education Contexts
}

\author{
Mahmood Hashemian \\ English Department, Shahrekord University, Shahrekord, Iran \\ Email:m72h@hotmail.com \\ Kamal Heidari Soureshjani \\ Young Researchers Club Member, Islamic Azad University, Shahrekord Branch, Shahrekord, Iran \\ Email: k_tefl_h@yahoo.com
}

\begin{abstract}
Among various variables affecting the learning of a language, motivation and autonomy play salient roles. The present study aimed at investigating the possible relationship among autonomy, motivation, and academic performance of Persian L2 learners. To do so, 60 Persian L2 learners from Shahrekord Payam-eNoor University were randomly selected to see whether or not autonomy, motivation, and academic performance are interrelated. Two questionnaires, one for autonomy and one for motivation, were employed to gather the required data. Analyzing the data through correlation and regression, the results revealed that there is a significant relationship between autonomy and academic performance, and also between motivation and academic performance. On the contrary, no significant relationship was observed between motivation and autonomy. The results of studies like the current one will help L2 teachers and curriculum developers make L2 learners more self-directed, motivated, and successful in conducting their own learning in distance contexts.
\end{abstract}

Index Terms - autonomy, motivation, academic performance, distance education

\section{INTRODUCTION}

The growth of information and information communication together with social and economic changes people are encountering as well as lack of access to adequate educational systems have increased the need for distance education. Accordingly, different economical, societal, educational, and political changes have been recently made to prepare the necessary conditions for distance education. Such technological, societal, and economical changes have led to fundamental transitions in educational systems, and consequently, provided distance education with a new prominent situation.

Distance education was launched in Russia in 1850 and then in Germany, Switzerland, Sweden, and finally in other countries. The first Open University was established in the U.K. in 1969, and then other countries including Iran developed this system. As to the basic concept of distance education, the Learning Circuits Glossary states that it is an educational situation in which the instructor and learners are separated by time, location, or both. In distance education, training courses are delivered to remote locations via synchronous or asynchronous means of instruction, such as written correspondences, graphics, audio- and video-tapes, CD-ROMs, online learning, audio- and videoconferencing, interactive TVs, and also facsimiles. Greenberg (1998) also defined distance education as the use of many different technologies to provide opportunities for learners at distance to reach their classmates and to encourage their interaction. The authors of the current paper also define distance education as one kind of instruction in which teachers and L2 learners are separate from each other and different technologies like video, data, print, CD, and so on are used to fill in this gap.

The important point with regard to distance education is that it never precludes the use of the traditional classroom. Rather, there may be held some classes for L2 learners. But because the total number of these classes, in comparison to the traditional classes, is few, these classes' times are mostly devoted to meeting the L2 learners' problems and removing their weaknesses, not teaching the materials completely from beginning to the end. In addition, in distance education because final exams are constructed by specific experts from the whole materials, L2 learners should selfstudy the whole predetermined materials for final exams. But in traditional education, exams are prepared by L2 teachers. Therefore, if they have not finished teaching the whole material, the final exam will just be limited to that covered part of the material.

Based on what is mentioned above, separation of L2 teachers and learners is a main feature of distance education. This gap between L2 teachers and learners puts a high responsibility on the shoulders of L2 learners. Distance L2 learners must be more responsible for their own learning. The term "distance learner" itself invites an assumption that an L2 learner of this type is expected to have gained, to some extent, learner autonomy (Januin, 2007).White (2003) 
also supports this claim by saying that distance or open learning leads to promoting learner autonomy. Moreover, distance or open learning involves a positive commitment to the widening access to education and the promotion of learner autonomy (Holmberg, 1986).

\section{BACKGROUND TO THE STUDY}

The concept of learner autonomy has attracted much attention and interest within the context of L2 learning, especially in the last two decades. Holec (1980) provided the definition of learner autonomy as, "the ability to take charge of one's own learning" (p. 3). Some scholars like Benson (2001) who advocate for autonomy are concerned primarily with the ability to learn effectively in terms of personal goals. Little (1991) also asserts that L2 learners can communicate efficiently in their L2 if they have enough autonomy to fulfill different social, psychological, and discourse roles. Furthermore, as Little (1991) states, autonomy in L2 learning and autonomy in L2 use are nonseparable concepts. Little, then, provides three pedagogical principles toward learner autonomy:

1. Learner empowerment

2. Learner reflection

3. Appropriate target language use

Little (1991) defines the above concepts as follows:

Learner empowerment requires learners to assume responsibility for their own learning and what amounts to the same thing giving them control of the learning process. Learner reflection helps learners to think about their learning both at a macro level, for example, reviewing what has been achieved in a school year and at a micro level, for example, trying to work out why a particular learning activity was or was not successful. Appropriate target language use requires the teacher to manage classroom discourse in such a way that learners are able to use the target language for genuine communicative purposes from the very beginning. (p.25)

In line with the aforementioned importance of autonomy, Deci and Vansteenkiste (2004) posited that autonomy is one of the three basic needs that L2 learners must satisfy in order to achieve a sense of self-fulfillment. An L2 learner is autonomous, they argued, when he or she is fully willing to do what he or she is doing and when he or she embraces the activity with a sense of interest and commitment (p. 2). Competence and relatedness are two other basic needs: One possesses a feeling of competence when they confront and successfully overcome optimal challenges ( $\mathrm{p} .66$ ), and they experience relatedness when they love and are loved by others (p. 88). Paiva (2006) also stated that autonomy is a sociocognitive system closely related to the L2 learning system. Paiva further explained that it involves not only the individual's mental states and processes, but also political, social, and economical dimensions. It is not a state, but a nonlinear process, which undergoes periods of instability, variability, and adaptability.

As to the relationship between autonomy and academic performance, some studies like that of Hurd (2006) have dealt with this issue. Hurd studied the relationship between autonomy, motivation, and success in the distance context and found that motivation, tutor feedback, and personal responsibility play a crucial role in successful academic performance. She also found that L2 learners' confidence and self-regulation could cause an increase in the process of learning at a distance education context.

It has been repeatedly pointed out that motivation plays a significant role in L2 learning and teaching process. And, one reason of its significance has been noted to be the fact that positive and lasting results in L2 learning are largely dependent on the existence of positive attitudes, and active as well as desirable investment of L2 learners (Overholser, 2005; Ryan \& Deci, 2008). L2 learners' motivation is also very important in distance education. It plays a key role on one's capacity to cope with the challenges of distance learning experiences (White, 2003). Keller (1984, as cited in Crookes \& Schmidt, 1991, p. 389) defines motivation as the choices people make as to what experiences or goals they will approach or avoid and the degree of the effort they will exert in that respect. A number of factors affect L2 learners' motivation in distance education: Loneliness, isolation, competing commitments, absence of the structuring aspects of face-to-face classes, and difficulty in adjusting to a distance L2 learning context are the salient ones (White, 2003). With more understanding about L2 learner's autonomy and motivation, L2 teachers and researchers can pinpoint more effective and suitable ways to train L2 learners to take more responsibility for their own learning and to cope with such loneliness and isolation of the learner and the teacher in such systems (White, 2003).

Regarding the relationship between motivation and distance learning, as White (2003) stated, changing the learning context may affect L2 learners' affective factors like motivation, empathy, and some other factors (White, 2003). In other words, L2 learners have to manage their environment, and instead of the teacher, they are faced with a lot of decision-making situations. They also need to take more responsibility in doing their own learning process, solving their problems, and identifying their outcomes. Besides, some studies revealed that L2 learners enter their courses of study with high initial motivation, but they cannot maintain that motivation up to the end of the course (Harris, 2003; Smith \& Sal, 2000).

Several studies have explored the effect of motivation on academic performance. For example, White (1995) studied the importance of affective factors on success in distance language learning. Her sample included novice Japanese and Spanish learners who studied in a distance context. She concluded that affective factors like motivation play a key role in L2 learners' success in a distance context.

Roohani (2001) also studied the motivational variables (integrative and instrumental) towards learning English as a 
foreign language among senior learners majoring in English at Shiraz State and Islamic Azad universities. The results indicated that the L2 learners at Shiraz State University were more integretively oriented as compared with their peers at Islamic Azad University. Moreover, a positive relationship was found between integrative motivation and proficiency level of the L2 learners.

To be specific about the Iranian context, learning English is an important issue in the educational system. Distance educational system can have facilitating or debilitating effects on the academic performance of Persian L2 learners in some aspects. One of the facilitating factors is learner autonomy. A teacher-centered education system, like that of Iran, may make many L2 learners alien to learning autonomy. L2 teachers in the traditional educational system in Iran take most of the responsibility, and most L2 learners are passive and are not responsible for the conduct of their own learning. Such learners encounter a lot of problems in distance education. They cannot be responsible for their own learning and may lose motivation to pursue higher education on a distance-learning system of education. Therefore, it is very important to consider the role of autonomy and motivation on L2 learners' academic performance success in the distance education for Persian L2 learners.

In light of the issues raised above, this study was an attempt to investigate the relationship between autonomy along with motivation and academic performance of Persian L2 learners. That is, the present study made an attempt to, first, explore if there is any relationship between L2 learners' grade point average (GPA) and their level of autonomy; second, if there is any relationship between L2 learners' GPA and their motivations; and finally, whether or not L2 learners' motivation and autonomy show any interrelationship.

Conducting studies like the present one can be a great help in a better and more effective teaching and learning of the English language. In other words, the results of studies like the current one may help L2 teachers and curriculum developers to make L2 learners more self-directed, motivated, and successful in conducting their own learning in a distance context. White (2003) argues that with more understanding about L2 learners' autonomy and motivation, L2 teachers and researchers are recognizing the importance of effective ways to train L2 learners to take more responsibility for their own learning and to cope with such loneliness and isolation of the learner and the teacher in such systems.

\section{METHODOLOGY}

\section{A. Participants}

The participants were 60 L2 learners from Shahrekord Payam-e-Noor University majoring in English Translation. They were 40 female and 20 male participants who were selected on the basis of their availability, whose age range was from 23 to 28 . Table 1 summarizes the basic features of the participants with regard to their GPA:

TABLE 1.

COMPOSITION OF THE PARTICIPANTS WITH REGARD TO GPA

\begin{tabular}{|c|c|c|}
\hline GPA & Frequency & Percent \\
\hline $15.32-18.37$ & 22 & 34.3 \\
\hline $14.20-15.31$ & 18 & 31.8 \\
\hline $12.34-14.19$ & 20 & 33.3 \\
\hline
\end{tabular}

\section{B. Materials}

In order to gather the required data, two questionnaires were employed. As to the first questionnaire, the Learner Autonomy Questionnaire developed by Kashefian (2002) was employed (Appendix A). This questionnaire consists of two main parts: The first part is related to the demographic information of the participants. And, the second part incorporates 40 items in a five-point Likert scale, all of which about the role of autonomy in L2 learning. As to the internal reliability of the questionnaire, Cronbach alpha was used which turned out to be almost 0.72 . For the validity, it was looked into by some professors of Shahrekord and Shiraz Universities and confirmed to be valid for the purpose of the present study. The second questionnaire (Appendix B) was the Motivation Questionnaire developed by Vaez (2008), which has two sections: The first part relates to the demographic information of the participants, and the second part consisting of 25 items is about motivation, of which 12 items are about integrative motivation and the rest are about instrumental motivation. Like the previous questionnaire, Cronbach alpha formula was used for its reliability which turned out to be 0.71 . And for its validity, it was confirmed by some of professors of Shahrekord and Shiraz Universities.

\section{Data Analysis}

The questionnaires were given to the participants. Prior to the administration of the instruments, the participants were provided with sufficient information about the purpose of the study by the researchers. Besides, they were also assured on the confidentiality of the results and the point that their responses and performance would be just for the purpose of conducting a research. The participants were requested to answer the questionnaires during their regular class time and without any time limit. 
Having gathered the data and in order to analyze them, the statistical program of SPSS, in general, and the Pearsonproduct moment formula, in particular, were run to investigate the probable relationship between motivation along with autonomy and the performance of the participants. Besides, in the case of the existence of the probable relationship between each pair of the variables, the Regression analysis was run to predict the variance in the dependent variable (i.e., GPA) from the variance in the independent variables (i.e., autonomy and motivation).

\section{RESUlTS}

First, the descriptive statistics of each of the understudied factors (i.e., GPA, autonomy, and motivation) are reported. The resulted descriptive statistics for the participants' academic achievement (i.e., GPA) shows that GPA ranges from a minimum of 12.3 to a maximum of 18.3 , with a mean of 14.8 and a standard deviation of 1.2. The same statistics for the second variable of the study, that is, autonomy, indicates that the scores ranged from 70.0 to 164.0, and mean and standard deviation are 1.2 and 21.9, respectively. And finally, as to the descriptive statistics of the third factor of the study, that is, motivation, the table indicates that the scores ranged from 61.0 (the lowest score on motivation) to 100.0 (the highest motivation level). Standard deviation is also 9.0.

In order to find out the possible relationship between each pair of the variables and also to find out the strength of any linear relationship, Pearson correlation analysis was run. Table 2 reports the results of the correlation analysis between GPA and autonomy. It reveals a significant positive relationship between GPA and autonomy $(r=.54, p<$ 0.01), meaning that the L2 distance learners who are more autonomous in English learning in Payam-e-Noor University can achieve better GPA in their studies. In addition, GPA and motivation have a positive significant relationship ( $r$ $=.385, p<0.01)$. In contrast, Table 2 also indicates that autonomy and motivation have a positive relationship but not significant $(r=.079, p>0.01)$. However, there are some other studies in which L2 learners' autonomy and motivation significantly correlate that are detailed in the following section:

TABLE 2.

RESUltS OF PEARSON CORRELATION ANALYSIS FOR GPA, AUTONOMY, AND MOTIVATION

\begin{tabular}{|c|c|c|c|c|}
\hline & & GPA & Autonomy & Motivation \\
\hline \multirow[t]{3}{*}{ GPA } & Pearson Correlation & 1 & $.547^{* *}$ & $.385^{* *}$ \\
\hline & Sig. (2-tailed) & & .000 & .002 \\
\hline & $N$ & 60 & 60 & 60 \\
\hline \multirow[t]{3}{*}{ Autonomy } & Pearson Correlation & $.547^{* *}$ & 1 & .079 \\
\hline & Sig. (2-tailed) & .000 & & .547 \\
\hline & $N$ & 60 & 60 & 60 \\
\hline \multirow[t]{3}{*}{ Motivation } & Pearson Correlation & $.385^{* * *}$ & .079 & 1 \\
\hline & Sig. (2-tailed) & .002 & .547 & \\
\hline & $N$ & 60 & 60 & 60 \\
\hline
\end{tabular}

With regard to the Regression analysis, because the correlation between autonomy and motivation was not significant, this procedure was used only for GPA (i.e., the dependent variable) and autonomy and motivation (i.e., the independent variables). Table 3 shows that the value of R2 (covariance) for autonomy is .41, meaning that autonomy and GPA share $41 \%$ of the variance between them:

TABLE 3.

MODEL SUMMARY GAINED FROM REGRESSION ANALYSIS

\begin{tabular}{|l|l|l|l|l|}
\hline Model & $R$ & $R$ Square & Adjusted R Square & Std. Error of the Estimate \\
\hline 1 & $.646^{\mathrm{a}}$ & .41 & .39 & 1.00 \\
\hline \multicolumn{5}{|c}{ a. Predictors: (Constant), Motivation, Autonomy }
\end{tabular}

And finally, based on Table 4, Beta values indicates that one standard deviation unit change in the score for autonomy will result in 0.52 unit of change in GPA. However, one standard deviation unit change in the score for motivation will result in 0.34 unit of change in GPA. Thus, on the whole, it can be inferred that autonomy scores are better predictors of GPA than motivation: 
TABLE 4.

COEFFICIENT TABLE

\begin{tabular}{|c|l|l|l|l|l|l|}
\hline \multirow{2}{*}{ Model } & \multicolumn{3}{|l|}{ Unstandardized Coefficients } & Standardized Coefficients & & \\
\cline { 2 - 6 } & B & Std. Error & Beta & $t$ & Sig. \\
\hline \multirow{2}{*}{1} & (Constant) & 6.837 & 1.389 & & 4.920 & .000 \\
\cline { 2 - 7 } & Autonomy & .031 & .006 & .520 & 5.127 & .000 \\
\cline { 2 - 6 } & Motivation & .050 & .015 & .344 & 3.392 & .001 \\
\hline
\end{tabular}

\section{DISCUSSION AND CONCLUSION}

The main objectives of this study were to explore the possible relationship among learner autonomy, academic performance, and motivation. It was noted that taking these variables into consideration will make a valuable contribution in the teaching and learning of every language. The study first revealed that there is a positive and significant relationship between autonomy and GPA. This finding is in line with the reports given by Grove, Wasserman, and Grodner (2006, cited in Januin, 2007) who studied the relationship between GPA scores and autonomy. They found that there was a positive significant relationship between autonomy and GPA.

The study also indicated a positive and significant relationship between motivation and GPA. In line with this finding, White (1995) also concluded that motivation plays a crucial role in L2 learners' success in a distance context. Gardner and Lambert (1972) further noted that integretively oriented persons achieve greater L2 competence.

As to the relationship between motivation and autonomy, the study revealed a positive but nonsignificant interplay. However, there are some studies that show the opposite of this finding. For example, Wang and Palincsar (1989, cited in Januin, 2007) found a positive relationship between being responsible for learning and motivation. They showed that putting responsibility on the shoulders of L2 learners and making them able to choose their goals independently will increase their motivation, and they can achieve their goals better. Cotterall (1999) also asserts that motivation can be an antecedent factor of successful autonomous learning.

All in all, the findings present several implications in the field of L2 teaching and learning. Regarding the factors which are of high importance in this study, L2 teachers should pay more attention to learner autonomy. Measuring learner autonomy and motivation at the beginning of each semester in distance education contexts, L2 teachers may probably make L2 learners more responsible for their own learning, and L2 learners would be provided with more motivation for learning. Further, when L2 teachers try to foster learner autonomy, L2 learners will have a different view of the distance context; as a result, they will adjust their expectations based on their experience of the new learning context. Another equally significant implication is that based on the principles of autonomy, syllabuses of the distance universities may need to be examined and probably redesigned. That is, on the basis of the criteria which can encourage L2 learners to foster their autonomy, course books should ideally be reevaluated. The other point is that because in distance contexts L2 learners experience some difficult situations and in most of these situations they need to make decisions, it is better to put into practice some in-service training on learner autonomy.

And finally, as to the Iranian context, self-directed learning in distance universities and what is prevalent in high schools is considerably different. The teacher-centered educational system in Iran decreases learner autonomy. Controlling and monitoring L2 learners' learning is different at universities and high schools. This difference causes too many difficulties with regard to taking responsibility for learning at distance universities. Some L2 learners may lose their motivation, and some may have problems in planning and monitoring their own learning process. As a result, it is very important to adjust L2 learners to the distance universities system and make them prepared to cope with its challenges.

Like any other study, this study suffers from a set of limitations. The main limitation is probably about the participants. That is, in order to reach much more reliable findings and also to be able to generalize the obtained findings of the study, further studies with more participants from different contexts need to be achieved. Another limitation of the study again related to the participants is that only advanced Persian L2 learners took part in the present study, and there could be other studies with elementary and intermediate Persian L2 learners and also with L2 learners who are learning English as a nonacademic course to get information about the interrelationship of the variables of this study in these two levels of proficiency.

\section{APPENDIX A LEARNER AUTONOMY QUESTIONNAIRE}

\begin{tabular}{|c|c|c|}
\hline $\begin{array}{l}\text { Sex: } \quad \ldots \ldots \ldots . . . \\
\text { Grade. }\end{array}$ & $\begin{array}{l}\text { Major: } \quad . . . . . . . . . . \\
\text { Age: }\end{array}$ & Marital Status: \\
\hline
\end{tabular}

Directions: Please show how much you agree or disagree with the following statements by circling the numbers which match your answers. 


\begin{tabular}{|c|c|c|c|c|}
\hline Strongly Agree & Agree & Neutral & Disagree & Strongly Disagree \\
\hline 1 & 2 & 3 & 4 & 5 \\
\hline
\end{tabular}

I believe ......

\begin{tabular}{|c|c|c|c|c|c|c|}
\hline 1 & The teacher should offer help to me. & 1 & 2 & 3 & 4 & 5 \\
\hline 2 & The teacher should tell me what my difficulties are. & 1 & 2 & 3 & 4 & 5 \\
\hline 3 & The teacher should tell me how long I should spend on an activity. & 1 & 2 & 3 & 4 & 5 \\
\hline 4 & The role of the teacher is to tell me what to do. & 1 & 2 & 3 & 4 & 5 \\
\hline 5 & The teacher should always explain why we do an activity in class. & 1 & 2 & 3 & 4 & 5 \\
\hline 6 & The role of the teacher is to help me leam effectively. & 1 & 2 & 3 & 4 & 5 \\
\hline 7 & The teacher knows best how well I am. & 1 & 2 & 3 & 4 & 5 \\
\hline 8 & The role of the teacher is to create opportunities for me to practice. & 1 & 2 & 3 & 4 & 5 \\
\hline 9 & The role of the teacher is to set my leaming goals. & 1 & 2 & 3 & 4 & 5 \\
\hline 10 & The teacher should be an expert at showing learners how to learn. & 1 & 2 & 3 & 4 & 5 \\
\hline 11 & The teacher should give me regular tests. & 1 & 2 & 3 & 4 & 5 \\
\hline 12 & Ineed the teacher to tell me how I am progressing. & 1 & 2 & 3 & 4 & 5 \\
\hline 13 & It is important to me to see the progress I make. & 1 & 2 & 3 & 4 & 5 \\
\hline 14 & I know how to check my works for mistakes. & 1 & 2 & 3 & 4 & 5 \\
\hline 15 & Having my works evaluated by others is helpful. & 1 & 2 & 3 & 4 & 5 \\
\hline 16 & Having my works evaluated by others is scary. & 1 & 2 & 3 & 4 & 5 \\
\hline 17 & I have a clear idea of what I need of English. & 1 & 2 & 3 & 4 & 5 \\
\hline 18 & I like try ing out new things by myself. & 1 & 2 & 3 & 4 & 5 \\
\hline 19 & My language learning success depends on what I do in classroom. & 1 & 2 & 3 & 4 & 5 \\
\hline 20 & My own efforts play an important role in successful language leaming. & 1 & 2 & 3 & 4 & 5 \\
\hline 21 & I myself can find the best way to learn the language. & 1 & 2 & 3 & 4 & 5 \\
\hline 22 & I know how to plan my leaming. & 1 & 2 & 3 & 4 & 5 \\
\hline 23 & I know how to ask for help when I need it. & 1 & 2 & 3 & 4 & 5 \\
\hline 24 & I know how to set my own learning goals. & 1 & 2 & 3 & 4 & 5 \\
\hline 25 & I know how my language leaming progresses. & 1 & 2 & 3 & 4 & 5 \\
\hline 26 & I know how to study languages well. & 1 & 2 & 3 & 4 & 5 \\
\hline 27 & I know how to study other subjects well. & 1 & 2 & 3 & 4 & 5 \\
\hline 28 & I have the ability to leam a language success fully. & 1 & 2 & 3 & 4 & 5 \\
\hline 29 & I have the ability to write accurately in English. & 1 & 2 & 3 & 4 & 5 \\
\hline 30 & I have the ability to get the score I try for in my next English test. & 1 & 2 & 3 & 4 & 5 \\
\hline 31 & I know how to find an effective way to leam English. & 1 & 2 & 3 & 4 & 5 \\
\hline 32 & I know best how well I learn. & 1 & 2 & 3 & 4 & 5 \\
\hline 33 & I have been successful in language learning. & 1 & 2 & 3 & 4 & 5 \\
\hline 34 & I have my own ways of testing how much I have learned. & 1 & 2 & 3 & 4 & 5 \\
\hline 35 & I am average at language learning. & 1 & 2 & 3 & 4 & 5 \\
\hline 36 & Making mistakes is a natural part of language learning. & 1 & 2 & 3 & 4 & 5 \\
\hline 37 & Making mistakes is harmful in language learning. & 1 & 2 & 3 & 4 & 5 \\
\hline 38 & It is possible to learn a language in a short time. & 1 & 2 & 3 & 4 & 5 \\
\hline 39 & Leaming a language takes a long time. & 1 & 2 & 3 & 4 & 5 \\
\hline 40 & I am above average at language learning. & 1 & 2 & 3 & 4 & 5 \\
\hline
\end{tabular}

\section{APPENDiX B MOTIVATION QUESTIONNAIRE}

Directions: Below are a number of statements with which some people agree and others disagree. We would like you to indicate your opinion about each statement by circling the number which best indicates the extent to which you disagree or agree with that statement.

Gender: Male $\bigcirc$ Female $\bigcirc$ Age:

The questions have a five-point answering scale. The numbers mean:

\begin{tabular}{|c|c|c|c|c|}
\hline Strongly Agree & Agree & Neutral & Disagree & Strongly Disagree \\
\hline 1 & 2 & 3 & 4 & 5 \\
\hline
\end{tabular}




\begin{tabular}{|c|c|c|c|c|c|c|}
\hline 1 & $\begin{array}{l}\text { Studying English can be important to me because it will allow me to be at ease with } \\
\text { other people who speak English. }\end{array}$ & 1 & 2 & 3 & 4 & 5 \\
\hline 2 & $\begin{array}{l}\text { Studying English can be important to me because it will allow me to meet and } \\
\text { converse with varied people. }\end{array}$ & 1 & 2 & 3 & 4 & 5 \\
\hline 3 & $\begin{array}{l}\text { Studying English can be important to me because it will enable me to better understand } \\
\text { and appreciate English arts and literature }\end{array}$ & 1 & 2 & 3 & 4 & 5 \\
\hline 4 & $\begin{array}{l}\text { Studying English can be important to me because I will be able to participate more } \\
\text { freely in the activities of other cultural groups. }\end{array}$ & 1 & 2 & 3 & 4 & 5 \\
\hline 5 & It is important to me to know English in order to know about English-speaking nations. & 1 & 2 & 3 & 4 & 5 \\
\hline 6 & Studying English is important to me so that I can understand English pop music. & 1 & 2 & 3 & 4 & 5 \\
\hline 7 & The more I get to know native English speakers, the more I like it. & 1 & 2 & 3 & 4 & 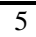 \\
\hline 8 & Studying English is important to me. & 1 & 2 & 3 & 4 & 5 \\
\hline 9 & $\begin{array}{l}\text { Studying English is important to me so that I can keep in touch with foreign friends } \\
\text { and acquaintances. }\end{array}$ & 1 & 2 & 3 & 4 & 5 \\
\hline 10 & I would like to know more about native-English speakers. & 1 & 2 & 3 & 4 & 5 \\
\hline 11 & The British are kind and friendly. & 1 & 2 & 3 & 4 & 5 \\
\hline 12 & The Americans are kind and cheerful. & 1 & 2 & 3 & 4 & 5 \\
\hline 13 & Studying English can be important to me because I will need it for my future job. & 1 & 2 & 3 & 4 & 5 \\
\hline 14 & $\begin{array}{l}\text { Studying English can be important to me because it will make me a more } \\
\text { knowledgeable person. }\end{array}$ & 1 & 2 & 3 & 4 & 5 \\
\hline 15 & $\begin{array}{l}\text { Studying English can be important because it will someday be useful in getting a good } \\
\text { job. }\end{array}$ & 1 & 2 & 3 & 4 & 5 \\
\hline 16 & $\begin{array}{l}\text { Studying English can be important to me because other people will respect me more if } \\
\text { I know English. }\end{array}$ & 1 & 2 & 3 & 4 & 5 \\
\hline 17 & $\begin{array}{l}\text { Studying English can be important to me because I will be able to search for } \\
\text { information and materials in English on the Internet. }\end{array}$ & 1 & 2 & 3 & 4 & 5 \\
\hline 18 & $\begin{array}{l}\text { Studying English can be important to me because I will learn more about what is } \\
\text { happening in the world. }\end{array}$ & 1 & 2 & 3 & 4 & 5 \\
\hline 19 & $\begin{array}{l}\text { Studying English can be important to me because language learning often gives me a } \\
\text { feeling of success. }\end{array}$ & 1 & 2 & 3 & 4 & 5 \\
\hline 20 & $\begin{array}{l}\text { Studying English can be important to me because language learning often makes me } \\
\text { happy. }\end{array}$ & 1 & 2 & 3 & 4 & 5 \\
\hline 21 & $\begin{array}{l}\text { Studying English can be important to me because an educated person is supposed to be } \\
\text { able to speak English. }\end{array}$ & 1 & 2 & 3 & 4 & 5 \\
\hline 22 & $\begin{array}{l}\text { Studying English can be important to me so that I can understand English-speaking } \\
\text { films, videos, TV, and radio. }\end{array}$ & 1 & 2 & 3 & 4 & 5 \\
\hline 23 & Studying English can be important to me so that I can read English books. & 1 & 2 & 3 & 4 & 5 \\
\hline 24 & $\begin{array}{l}\text { Studying English is important to me because it will enable me to get to know new } \\
\text { people from different parts of the world. }\end{array}$ & 1 & 2 & 3 & 4 & 5 \\
\hline 25 & $\begin{array}{l}\text { Studying English is important to me because without it one cannot be successful in any } \\
\text { field. }\end{array}$ & 1 & 2 & 3 & 4 & 5 \\
\hline
\end{tabular}

\section{REFERENCES}

[1] Benson, P. (2001). What is autonomy? Hong Kong: The English Center, the University of Hong Kong:

[2] Cotterall, S. (1999). Key variables in language learning: What do learners believe about them? System 27.1, 493-513.

[3] Crookes, G. \& Schmidt, R. W. (1991). Motivation: Reopening the research agenda. Language Learning 41, 469-512.

[4] Deci, E. L. \& Vansteenkiste, M. (2004). Self-determination theory and basic need satisfaction: Understanding human development in positive psychology. Richerche di Psichologia 27, 17-34.

[5] Gardner, R. C. \& Lambert, W. E. (1972). Attitudes and motivation in second language learning. Rowley, MA: Newbury House.

[6] Greenberg, G. (1998). Distance education technologies: Best practices for K-12 settings. IEEE Technology and Society Magazine 17.4, 36-40.

[7] Grove, W. A., Wasserman, T. \& Grodner, A. (2006). In J. Januin (Ed.), Exploring readiness for language learning autonomy among distance learners in Sabah. Sabah: Malaysia, 131-148.

[8] Harris, V. (2003). Adapting classroom-based strategy instruction to a distance learning context. TESL-EJ 7, 1-17.

[9] Holec, H. (1980). Autonomy and foreign language learning. Nancy: Centre de Recherchéet d'Applications Pedagogiques en Langsues, Council of Europe.

[10] Holmberg, B. (1986). Growth and structure of distance education. London: Croom Helm.

[11] Hurd, S. (2006).Towards a better understanding of the dynamic role of the distance language learner: Learner perceptions of personality, motivation, roles and approaches. Distance Education 27.3, 299-325.

[12] Januin, J. (Ed.) (2007). Exploring readiness for language learning autonomy among distance learners in Sabah. Sabah: Malaysia.

[13] Kashefian, S. N. (2002). An investigation into college EFL learners' beliefs demonstrating their predispositions Towards learner autonomy. Unpublished master's thesis, Shiraz University, Shiraz. 
[14] Keller, J. (1984). In G. Crookes, G. \& R. W. Schmidt (1991), Motivation: Reopening the research agenda. Language Learning 41, 469-512.

[15] Little, D. (1991). Learner autonomy 1: Definitions, issues and problems. Dublin: Authentik.

[16] Overholser, J. C. (2005). Contemporary psychotherapy: Promoting personal responsibility for the therapeutic change. Journal of Contemporary Psychotherapy 35, 369-376.

[17] Paiva, V. L. (2006). Autonomia e complexidade. Linguagem e Ensino 9.1, 77-127.

[18] Roohani, A. (2001). An investigation into learners' integrative and instrumental motivations in the state and Islamic Azad universities of Shiraz. Unpublished master's thesis, Shiraz University, Shiraz.

[19] Ryan, R. M. \& Deci, E. L. (2008). A self-determination approach to psychotherapy: The motivational basis for effective change. Canadian Psychology 49, 186-193.

[20] Smith, M. \& Sal, U. (2000).Web-based ESL courses: A search for industry standards. CALL-EJ Online 2.1, 34-57.

[21] Vaezi, Z. (2008). Language learning motivation among Iranian undergraduate learners. World Applied Sciences Journal 51, 54-61.

[22] Wang, M. C. \& Palincsar, A. S. (1989). In J. Januin (Ed.), Exploring readiness for language learning autonomy among distance learners in Sabah. Sabah: Malaysia, 120-131.

[23] White, C. (1995). Autonomy and strategy use in distance foreign langue learning: Research findings. System 23.2, $207-221$.

[24] White, C. (2003). Language learning in distance education. Cambridge: Cambridge University Press.

Mahmood Hashemian is an assistant professor at Shahrekord State University. His area of research includes cognitive-semantic linguistics, sociolinguistics, and applied linguistics. He has published articles in academic journals and given lectures in conferences such as TELLSI $(4,7, \&$ 8), LDP2010, and ELT in the Islamic World.

Kamal Heidari Soureshjani holds an M.A. in TEFL from Shiraz University and is a Young Researchers Club Member. He has taught English courses and IELTS at different institutes in Shiraz and is presently the academic member of Islamic Azad University, Shahrekord Branch. 